NEWS

\section{Not so sunny after all}

\section{Manufacturers in the solar-energy industry are downsizing and scaling back their once-ambitious plans. Katharine Sanderson reports.}

Lay-offs, stalled projects and grim financial forecasts are affecting the solar-energy industry, which until recently had been growing with little end in sight.

In November 2008, BP Solar announced that it would be closing a photovoltaics factory in Sydney,

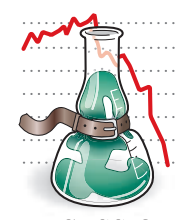

RECESSION WATCH funding rounds. "We suspended construction in November as it became obvious that access to capital was not available," says spokesman Alan Bernheimer. Nearly half the company's workforce, or 300 employees, will be let go.

Some legislative incentives that could help the industry are on the horizon. Last October, the US Congress extended for another eight years the $30 \%$ tax credit for those who invest in renewable-energy projects. But many investment firms aren't making enough money to take advantage of the credit. "This is probably the biggest problem for US industry," says Jenny Chase, a Londonbased analyst for New Energy Finance. The Solar Energy Industries Association in Washington DC has called for the incentives to be made refundable so that investors can claim them even if they are not making money.

The economic stimulus package proposed by the US House of Representatives last week (see page 364) doesn't include such a plan, but it does contain a US $\$ 8$-billion loan guarantee programme for renewable energy technologies. If passed, this proposal could help OptiSolar, which is applying now for loan guarantees from the government. "We seem to be just what they're talking about," says Bernheimer. Still, even Monique Hanis, director of communications for the industry organization, says that "these are just proposals. There's a lot of work to be done."

Current tax incentives also don't cover solarcell manufacturers, notes B. J. Stanbery, chief executive of HelioVolt, a company in Austin, Texas, that manufactures copper-indiumgallium-selenide solar cells. HelioVolt, which is just about to bring its first manufacturing plant online, has also made or $10 \%$ of its work force.

One of the most dramatic cutbacks has come at OptiSolar of Hayward, California. The company has been planning to open the largest photovoltaics power plant in the world, a 550-megawatt facility in San Luis Obispo county in California, by 2013. OptiSolar says it still intends to build the plant even though it has been unable to raise money in its latest some employees redundant, but won't say how many. Stanbery says that the redundancies were part of the process of shifting from research and development to manufacturing, rather

"This was always
likely to be the
year when supply
overtook demand."
than because of the economic crisis. "Frankly,
it had more to do with adjusting the skills mix in the company," he says.

Stanbery predicts that his company will survive as it is young and small - it expects to generate 20 megawatts this year from its production facility in Austin. "I don't think it's going to be a really tough year for us," he

\title{
Translational research in Berlin hits a roadblock
}

\begin{abstract}
A historic biomedical research campus in former East Germany is retrenching after a prolonged political attack. Unproven accusations alleged that $€ 15$ million (US\$20 million) of state money had flowed illegally into the private Helios hospital in the Berlin suburb of Buch. Clinical researchers there now find themselves struggling to rebuild collaborations with basic scientists.
\end{abstract}

The dispute concerns a contract forged in 2001 between a national research centre, the Max Delbrück Center for Molecular Medicine, and two hospitals: Helios, which is private, and the Charité, which is Berlin's teaching hospital. The aim was to promote translational research. But the hospitals terminated the contract in
December 2008 "because we felt that the scandalizing would never stop unless we did", says Karl Max Einhäupl, head of Charité. Einhäupl says that dividing funds between research and patient care is always complicated, but that he doesn't think any state money was used inappropriately.

Buch developed over the past century as a state-of-the-art biomedical and clinical campus. After reunification, the former West German research system absorbed the basic-research institute but not its clinical facilities, which were eventually privatized.

Keen to improve the parlous state of translational clinical research in Germany - something that East Germany had done well in Buch - the German government helped to facilitate an agreement with the private sector. Clinicians from Charité's medical school were appointed to head clinics at Helios, and their salaries were shared

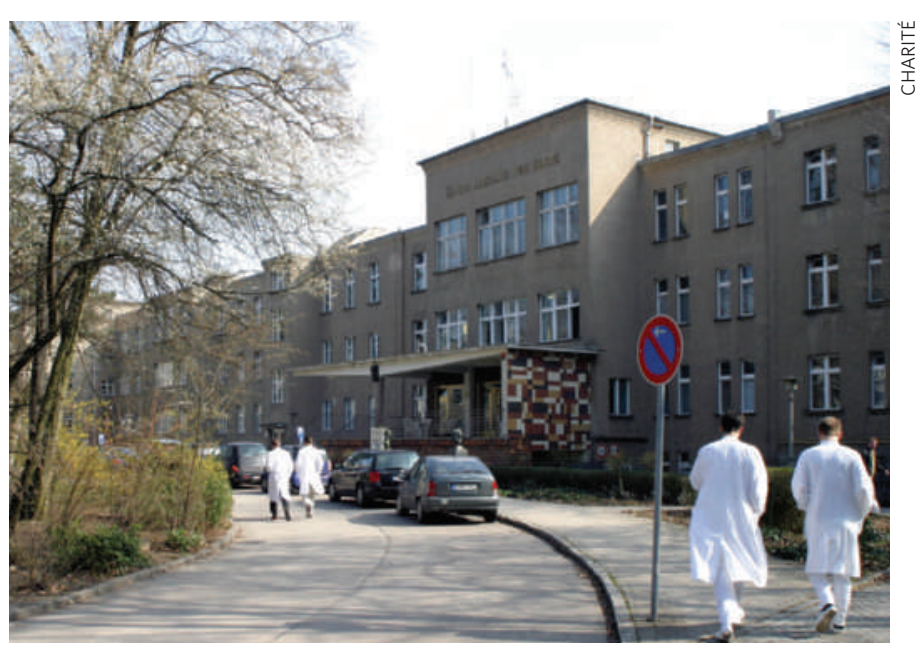

The Buch biomedical campus in northeast Berlin is home to large lab facilities.

between the hospitals. This gave clinicians with research interests convenient access to the laboratory facilities at Buch. 


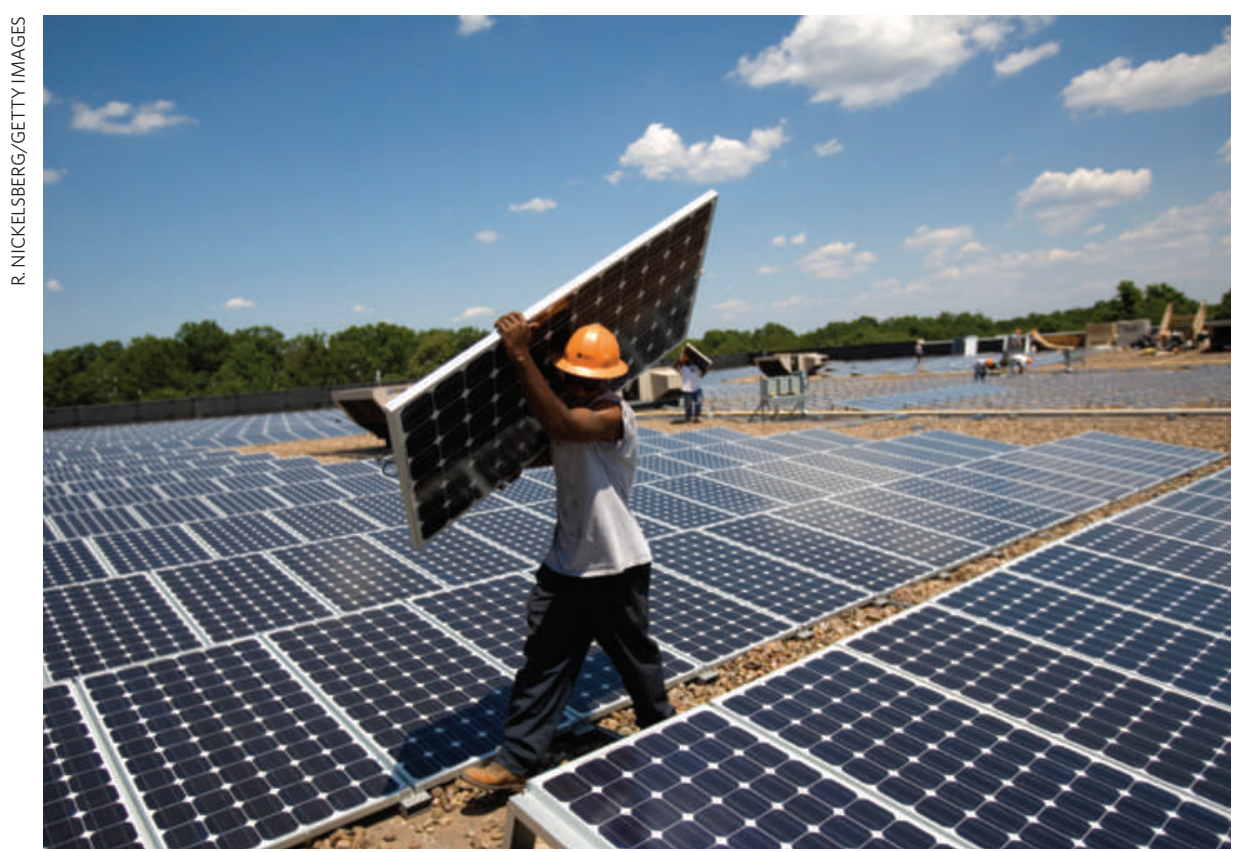

Solar panels are now being made faster than they can be sold.

says. For others in the solar industry at large, he predicts, "it is going to be brutal".

Solar's rapid growth in recent years has coloured expectations for the field, says Ken Zweibel, director of the Institute for the Analysis of Solar Energy at George Washington University in Washington DC. "Solar has been on a $40-50 \%$ growth rate for ten years now," he says. "What we're losing is that growth rate."

This year was always going to be tough for solar, says Chase. In Europe in particular, four years of generous subsidies have encouraged new players to join the fray, leading to a surge of solar modules on the market. "This was always

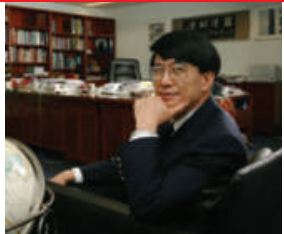

INTERVIEW: PAUL CHU

Hong Kong inaugurates Institute for Advanced Study.

www.nature.com/news likely to be the year when supply overtook demand," she says. In Spain, the government's incentive scheme was so popular that roughly 3 gigawatts of solar-power capacity were connected to the grid in 2008, and authorities are investigating reports of fraudulent hook-ups. The Spanish government has since capped this year's production subsidies at 500 megawatts.

In Bitterfeld-Wolfen, Germany, solar-cell manufacturer Q-Cells closed its facilities temporarily over the Christmas-New Year period to save money. Q-Cells has also put on hold plans to build a silicon wafer and ingot plant in Malaysia. "We will have to focus on our core business - increasing cell production," says says spokesman Stefan Dietrich. "There's not much money around."

In December, Q-Cells reduced its forecast net income for the 2008 financial year from $€ 215$ million (US\$286 million) to $€ 185$ million. Similarly, the Chinese company LDK Solar, in Xinyu, Jiangxi province, cut its 2008 forecast from a maximum in revenue of $\$ 565$ million to a maximum of $\$ 435$ million.

One thing is sure, says Chase: the prices of solar modules will plummet in 2009 because of the oversupply. But low prices could mean that the developing world gets better access to solar power, or attracts investors to companies that had been flagging. "I think the return on solar will go up," she says. It's just that some companies won't make it that long.
But Germany has always been uncomfortable with public-private partnerships, particularly within the cash-strapped health system. For more than a year, politicians had been piling pressure on the hospitals, suggesting that public money was seeping into patient care under the guise of research. Two investigations by the consultancy firm PricewaterhouseCoopers failed to disentangle the payments, but concluded that there was "no badly intentioned, deliberate crosstransfer of funds".

Now that the contract has been terminated, clinic heads at Helios have had to decide whether to stay with the hospital and lose their academic status, or move into the city at Charité and lose convenient access to the Buch laboratory facilities.

In the future, the Max Delbrück Center will collaborate with Helios on a project-by-project basis with much paperwork to specify who pays for what.

"The flow of finance will be clearer this way, but [the new bureaucracy] doesn't make our lives particularly pleasant," says Frederick Luft, a nephrologist and hypertension expert who decided to stay with Helios so that he could stay in Buch. "It makes a big difference to be able to walk 10 minutes between the hospital and the lab," he says.

Many of Luft's colleagues also believe that the distance between suburban Buch and the downtown Charité clinics, which can take up to an hour on public transport, makes collaborations less attractive.

"Translational research works best when clinicians and basic scientists meet on a daily basis," says Detlev Ganten, founder of the Max Delbrück Center, former Charité chief and architect of the public-private collaboration contract in 2001. Still, he says,
"Buch is not as disconnected as it was, and it will be possible to get things to work again."

Another part of the effort to promote translational research at Buch has also run into trouble.

A publicly funded Experimental and Clinical Research Center had been planned to be built on Helios land in 2001, but will now be built a few hundred metres away, next to the Max Delbrück Center, instead. The change will delay its planned 2011 opening by at least a year. Collaborations between the Max Delbrück Center and the Charité, both of which are publicly funded, will now intensify and be organized through the Experimental and Clinical Research Center.

This week, the Buch campus sees at least one piece of good news. Research minister Annette
Schavan is scheduled to open an ambitious new $€ 10$-million magnetic resonance imaging facility at the Max Delbrück Center. It includes a 7-tesla imager for use in humans, and a 9.4-tesla imager for animals.

Aside from their more conventional use to look inside the brain, the machines will for imaging the beating heart, a challenge very few groups around the world are attempting. The facility is meant as another step in Germany's embrace of translational research in medicine. "Imaging is an important bridge between basic research and medicine," says pharmacologist Walter Rosenthal, scientific director of the Max Delbrück Center.

Alison Abbott 